\title{
Effects of dietary mono- and multiprobiotic strains on growth performance, gut bacteria and body composition of Javanese carp (Puntius gonionotus, Bleeker 1850)
}

\begin{abstract}
This study investigated the effects of dietary mono- and multiprobiotic strains of Enterococcus faecalis, Lactobacillus fermentum and Leuconostoc mesenteroides on growth performance, intestinal bacteria and body composition of Javanese carp (Puntius gonionotus). Moreover, the effect of storage temperature on lactic acid bacteria (LAB) viability in the feed was studied. Compared to the control group, significant $(\mathrm{P}<0.05)$ effect on weight gain, feed conversion ratio, specific growth rate and protein efficiency ratio of probiotic fed Javanese carp was observed. Inclusion of individual LAB strains in the diet resulted in significantly improved growth performances of Javanese carps compared to fish fed a diet supplemented LAB mixture. The inclusion level of E. faecalis at 107 colony-forming unit (cfu) gī 1 in the diet revealed higher growth performance compared to other treatments. The population levels of LAB in the fish intestine were significantly increased while the levels of Gram-negative bacteria were significantly decreased compared to the control. No significant variations were observed in the chemical composition of the carcass by probiotics. The viability of LAB in feed was higher when stored at $4^{\circ} \mathrm{C}$ compared to $25^{\circ} \mathrm{C}$. It is suggested that E. faecalis has a greater potential for use in improving Javanese carp culture outcomes.
\end{abstract}

Keyword: Carcass composition; Growth performance; Intestinal microbiota; Javanese carp; Probiotic 